Jurnal Informatika dan Rekayasa Perangkat Lunak (JATIKA)
Vol. 2, No.3, September 2021, page-page. 312 323
ISSN 2723-3367
E-ISSN 2797-3492
available online at:http://jim.teknokrat.ac.id/index.php/informatika

\title{
APLIKASI RESTFULL PADA SISTEM INFORMASI GEOGRAFIS PARIWISATA KOTA BANDAR LAMPUNG
}

\author{
Melvitasari Tinambunan ${ }^{1}$, Sanriomi Sintaro ${ }^{2}$ \\ Universitas Teknokrat Indonesia ${ }^{1,2}$ \\ melvitasari_tinambunan@teknokrat.ac.id
}

Published: 30 September 2021

\begin{abstract}
Android, Geographic Information Systems, RESTful, Web One of the mapping technologies widely used today is Geographic Information Systems. Geographic Information Systems (GEOGRAPHIC INFORMATION SYSTEMS) is a mapping technology in the form of computer-based information systems, designed to work using data that has spatial information or spatial reference. Mapping technology is widely used to facilitate human work. In this research, Geographic Information System technology was used to support one of the business processes at the Bandar Lampung City Tourism Office. This system was built to assist related agencies in recording tourist sites. The system consists of a web-based system and Android-based applications that are connected using RESTful Web Service. The system is implemented using the PHP programming language with the help of CodeIgniter for webbased systems, and the Java programming language for Android-based applications. The method of developing the system used is the waterfall model method according to Rossa U.S. and Saladin (2014). Application design is based on Unified Modeling Language (UML), flowchart diagrams, and interface design. While the application used in the creation of the Android base system is Android Studio. The testing method used is the system's functional Black-Box. The results of black-box testing data show that the system runs as it should, the system is easy to understand by users, and can meet the functional needs of the system needed by the Bandar Lampung City Tourism Office.
\end{abstract}

Keywords: Android, Geographic Information System, RESTful, Web Service.

\begin{abstract}
Abstrak
Salah satu teknologi pemetaan yang banyak digunakan saat ini adalah Sistem Informasi Geografis. Sistem Informasi Geografis yang sering disebut dengan GIS (Geographic Information System) merupakan teknologi pemetaan berupa sistem informasi berbasis komputer, yang dirancang untuk bekerja dengan menggunakan data yang memiliki informasi spasial atau bereferensi keruangan. Teknologi pemetaan banyak digunakan untuk mempermudah pekerjaan manusia. Dalam penelitian ini, teknologi Sistem Informasi Geografis digunakan untuk mendukung salah satu proses bisnis pada Dinas Pariwisata Kota Bandar Lampung. Sistem ini dibangun untuk membantu instansi terkait dalam melakukan pencatatan lokasi wisata. Sistem ini terdiri dari sistem berbasis web dan aplikasi berbasis Android yang terhubung dengan menggunakan RESTful Web Service. Sistem diimplementasikan dengan menggunakan bahasa pemrograman PHP dengan bantuan CodeIgniter untuk sistem berbasis web, dan bahasa pemrograman Java untuk aplikasi berbasis Android. Metode pengembangan sistem yang digunakan adalah metode model air terjun (waterfall) menurut Rossa A.S dan Shalahuddin (2014). Perancangan aplikasi dibuat berdasarkan Unified Modeling Language (UML), diagram alir (flowchart), dan rancangan interface. Sedangkan aplikasi yang digunakan dalam pembuatan sistem basis Android adalah Android Studio. Metode pengujian yang digunakan adalah Black-Box fungsional sistem. Hasil data pengujian Black-Box menunjukkan bahwa sistem berjalan sebagaimana mestinya, sistem mudah dimengerti oleh pengguna, dan dapat memenuhi kebutuhan fungsional sistem yang dibutuhkan Dinas Pariwisata Kota Bandar Lampung.
\end{abstract}

Kata Kunci: Android, Sistem Informasi Geografis, RESTful, Web Service. 
To cite this article:

Melvitasari Tinambunan, Sanriomi Sintaro. (2021). APLIKASI RESTFULL PADA SISTEM INFORMASI GEOGRAFIS PARIWISATA KOTA BANDAR LAMPUNG. Jurnal Informatika dan Rekayasa Perangkat Lunak, Vol(2) No(3), 312-323.

\section{PENDAHULUAN}

Sistem informasi dibuat dan dibangun dengan baik agar meningkatkan produktivitas, menghilangkan kegiatan yang tidak memiliki manfaat, meningkatkan layanan, mengkoordinasikan setiap bagian dalam perusahaan serta meningkatkan kualitas kebijakan dalam manajemen (Fariyanto et al., 2021; Wahyudi, 2020). Sistem informasi yang baik dapat digunakan tidak hanya untuk penyimpanan data secara elektronik saja tetapi harus mampu mendukung proses analisis yang diperlukan oleh manajemen, karena dengan adanya laporan yang tersaji dengan cepat dan setiap saat dapat diakses tersebut maka keputusan-keputusan yang diambil pun dapat lebih cepat dan tepat terhadap dinamika pasar yang ada (Puspaningrum et al., 2020; Satria et al., 2020; Sintaro et al., 2020).

Kota Bandar Lampung adalah salah satu kota di provinsi Lampung yang mempunyai potensi pariwisata lebih untuk dikembangkan. Saat ini, masyarakat memilih ke tempat wisata untuk berlibur. Sektor wisata yang beragam dengan keunikannya, dan didukung dengan fasilitas serta sarana transportasi yang tersedia di kawasan wisata dapat memberikan income yang sangat besar untuk pemerintah atau pedagang yang berjualan di sekitar kawasan wisata. Menurut Dinas Pariwisata Kota Bandar Lampung, Kota Bandar Lampung merupakan salah satu destinasi wisata Provinsi Lampung yang memiliki banyak objek wisata yang perlu dikembangkan atau ditingkatkan guna dijadikan sebagai peluang untuk meningkatkan Pendapatan Asli Daerah. Kota Bandar Lampung memiliki beberapa kawasan yang berpotensi untuk dikembangkan menjadi daerah objek tujuan wisata karena didukung topografi tinggi berbukit dan dataran rendah dekat dengan pantai yang diarahkan sebagai kawasan pendukung pariwisata. Menurut Dinas Pariwisata Kota Bandar Lampung, pada tahun 2017 terdapat 54 objek wisata dari 5 kategori wisata (Wisata Sejarah dan Religi, Wisata Cagar Alam / Alam, Wisata Bahari / Laut, Wisata Kuliner, dan Wisata Belanja) di Kota Bandar Lampung yang dikelola secara mandiri (swasta).

Wisbalam (Wisata Bandar Lampung) adalah sebuah solusi yang mampu menggali potensi sekaligus menjadi wadah informasi pariwisata Kota Bandar Lampung. Informasi pada Wisbalam ini diharapkan mampu diakses tidak hanya wisatawan dalam negeri melainkan wisatawan mancanegara yang ingin mencari tujuan wisata di Bandar Lampung.

Teknologi Sistem Informasi Geografis (SIG) telah berkembang pesat (Rahmanto et al., 2020). SIG dibuat dengan menggunakan informasi yang berasal dari pengolahan sejumlah data, yaitu data geografis atau data yang berkaitan dengan posisi objek di permukaan bumi (Ahdan \& Setiawansyah, 2020). Teknologi SIG mengintegrasikan operasi pengolahan data berbasis database yang bisa digunakan saat ini, seperti pengambilan visualisasi yang khas melalui gambar yang tertera dipeta (Ahdan \& Setiawansyah, 2021). SIG dapat disajikan dalam bentuk aplikasi desktop maupun aplikasi berbasis web. SIG juga dapat memberikan penjelasan tentang suatu pariwisata.

Aplikasi tersebut akan dikembangkan dan ditanamkan secara lebih luas baik dari segi resource maupun dari segi layanan aplikasi (Mustaqov \& Megawaty, 2020). Hal tersebut sesuai dengan tren wisatawan yang lebih berkeinginan agar sebuah informasi dari aplikasi dapat diakses oleh berbagai macam perangkat dan aplikasi (Darwis et al., 2020). Aplikasi Wisbalam diharapkan mampu diakses melalui sebuah web. Data-data yang ada pada Wisbalam diharapkan dapat diakses oleh berbagai perangkat lain. Wisbalam juga diharapkan mampu mengkonsumsi data yang tersebar di kantor pariwisata Kota Bandar Lampung yang dimana setiap jabatan seksi bidang menangani objek wisata berdasarkan tipe atau klasifikasinya. Oleh karena itu diperlukan perancangan sebuah sistem Web service untuk Aplikasi Peta Wisata Kota Bandar Lampung. Web service memungkinkan terbentuknya sebuah layanan terpadu bagi para wisatawan agar mendapatkan informasi yang diinginkan secara tepat (Rahmanto \& Fernando, 2019; Setiawansyah et al., 2021).

Web service adalah sistem perangkat lunak yang dirancang untuk mendukung interaksi yang bisa beroperasi machine-to-machine diatas jaringan (Budiman et al., 2019). Web service mempunyai alat penghubung yang diuraikan didalam format machine-processable (secara spesifik WSDL). Sistem lain saling berhubungan dengan Web service didalam cara yang ditentukan oleh deskripsinya yang menggunakan pesan SOAP, secara khas disampaikan dengan HTTP dengan XML serialization, bersama dengan standar lain yang terkait dengan web (Ramadhanu \& Priandika, 2021; Riskiono et al., 2020).

Sistem Web service yang digunakan oleh Wisbalam adalah untuk pertukaran informasi data antara server pusat Wisbalam dan server-server ditiap seksi bidang. Dengan menggunakan web service, diharapkan mampu menjadi jembatan penghubung sistem komunikasi antara server pusat Wisbalam dan server - server dibagian seksi bidang. 


\section{TELAAH PUSTAKA}

PT Essei Perbama adalah Perusahan yang bergerak dibidang distributor barang yaitu Saos, Biskut dan makanan ringan lainya. Pada distributor barang di PT Essei Perbama masih menggunakan proses manual yaitu sales datang ke toko-toko / Agen untuk menawarkan produk dan mencatat data pemesanan barang dengan menggunakan kertas, kemudian memberikan data pemesananya ke admin ketika selesai keliling toko pada waktu sore hari ketika jam kerja berakhir. Ketidakefektivan itu karena masih menggunakan pencatatan manual dan admin harus menunggu sales datang ke perusahaan. Metodologi pengembengan sistem yang digunakan untuk pengembangan sistem membuat aplikasi mobile dan web ini yaitu metode SDLC, sedangkan metode untuk implementasikan web service yaitu metode Representational state transfer (REST) yang dibangun dengan menggunakan framework ionic hybrid apps yang dapat berjalan diapliksi mobile dan web dengan memanfaatkan Google Firebase sebagai web service dan realtime database. Hasil penelitian ini adalah membuat aplikasi berbasis mobile dan web dengan mengimplementasikan web service maka sales dan admin dapat terintegrasi meskipun berbeda platform sehingga mempermudah kinerja sales dalam melakukan pemesanan barang kepada admin. Dapat disimpulkan dari penelitian ini bahwa implementasi web service dalam pengembangan aplikasi mobile dan web dapat digunakan untuk solusi pada aplikasi sales order untuk menghubungkan dengan database terpusat meskipun berbeda platform (Butsianto \& Iskianto, 2020).

Sensus merupakan suatu kegiatan secara berkala yang dilakukan untuk mengetahui jumlah penduduk berdasarkan kategori tertentu. Sensus yang dilakukan menggunakan metode door-to-door kurang efektif dan efisien karena membutuhkan waktu, tenaga dan biaya yang sangat besar. Permasalahan tersebut dapat diselesaikan dengan mengintegrasikan RESTFul Web Service pada perangkat android (Gotama et al., 2021; Kurniawan et al., 2020). Tujuan pengembangan aplikasi berbasis android ini agar proses pengumpulan data lebih sistematik dan efisien. Hasil dari penelitian ini adalah aplikasi berbasis android yang mengimplementasikan RESTFul web service (Kurniawati, 2016).

Kesulitan dalam mengintegrasikan data pada beberapa sistem yang berbeda menjadi salahsatu masalah yang sering dialami oleh developer, mulai dari bahasa pemrograman, Platform, dan perangkatyang digunakan. Oleh sebab itu, perlu adanya pembuatan web service untuk sistem informasi akademikSTT Terpadu Nurul Fikri dengan teknologi REST. Perancangan ini dibuat dua model API untuk duamodul yakni modul mahasiswa dan modul dosen. Pada modul ini akan menghasilkan data dengan formatJSON. Teknik pengujian API menggunakna teknik blackbox testing dengan tools aplikasi pengujiPostman. Pengujian API dilakukan pada prototype aplikasi web service. Metode penelitian yang digunakanadalah Unified Process yang menggunakan kerangka kerja Yii Framework 2.0 (Arianto, 2016).

\section{METODE PENELITIAN \\ Teknik Pengumpulan Data}

Metode pengumpulan data yang dipakai dalam penelitian ini untuk memperoleh data- data penelitian dengan cara

1. Studi Pustaka (Library Research)

Studi Pustaka dilakukan dengan cara mengambil beberapa sumber pustaka sebagai referensi yang terkait dengan penyusunan laporan yang diperlukan, hal ini dimaksudkan agar dapat memecahkan masalah berdasarkan teori-teori yang ada (Damayanti \& Sulistiani, 2017).

2. Dokumentasi (Documentation)

Dokumentasi atau metode pengumpulan data dilakukan dengan cara membaca, mencatat, mengutip, dan mengumpulkan data-data secara teoritis dari buku-buku dan internet sebagai landasan penyusunan penelitian (Alim et al., 2020). Dokumentasi dilakukan dengan meminjam buku di perpustakaan, mencari data dari internet juga dilakukan untuk referensi laporan ini, dimana teori tersebut diletakkan pada landasan teori (Surahman et al., 2020).

\section{Analisis Kebutuhan Sistem}

Analisis kebutuhan fungsional memiliki jenis kebutuhan yang berisikan proses - proses apa saja yang dibutuhkan oleh sistem yang dirancang (Agustina \& Isnaini, 2020; Nugroho et al., 2021).

1. User masuk kedalam aplikasi Implementasi Restful Service pada Sistem Informasi Geografis Zona Wisata Kota Bandarlampung Berbasis Android, lalu akan tampil Menu Utama. 
2. User dapat memilih menu Tambah Wisata Baru yang akan menampilkan form tambah wisata, lalu user input data wisata yang dituju.

3. User dapat memilih menu Kategori Wisata jika user telah mengetahui wisata yang dituju, lalu sistem akan menampilkan map lokasi wisata yang dicari beserta rutenya.

4. User dapat memilih menu Lihat Peta jika ingin melihat marker peta wisata secara keseluruhan.

5. User dapat memilih menu Bantuan Aplikasi jika membutuhkan bantuan dalam penggunaan Implementasi Restful Service pada Sistem Informasi Geografis Zona Wisata Kota Bandarlampung Berbasis Android.

6. User dapat memilih menu Tentang Kami jika ingin mengetahui lebih detail tentang Implementasi Restful Service pada Sistem Informasi Geografis Zona Wisata Kota Bandarlampung Berbasis Android.

7. User dapat memilih menu Keluar Aplikasi jika ingin keluar dari sistem.

\section{HASIL DAN PEMBAHASAN}

\section{Use Case Diagram Android}

Berikut ini adalah bentuk dari use case diagram yang digambarkan dalam perancangan sistem.

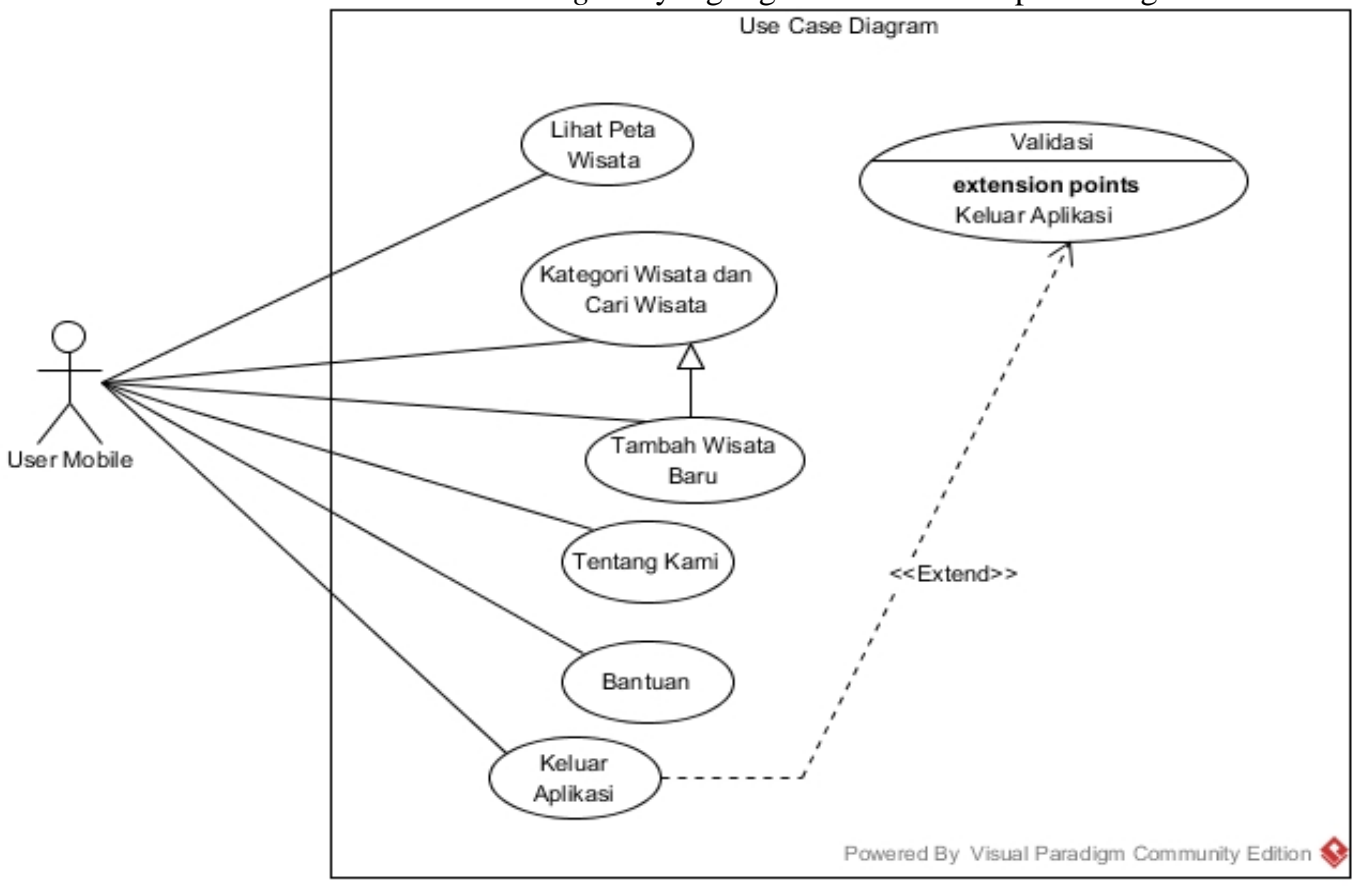

Gambar 1. Use Case Diagram Android

Use Case Diagram Web

Berikut ini adalah bentuk dari use case diagram yang digambarkan dalam perancangan sistem. 


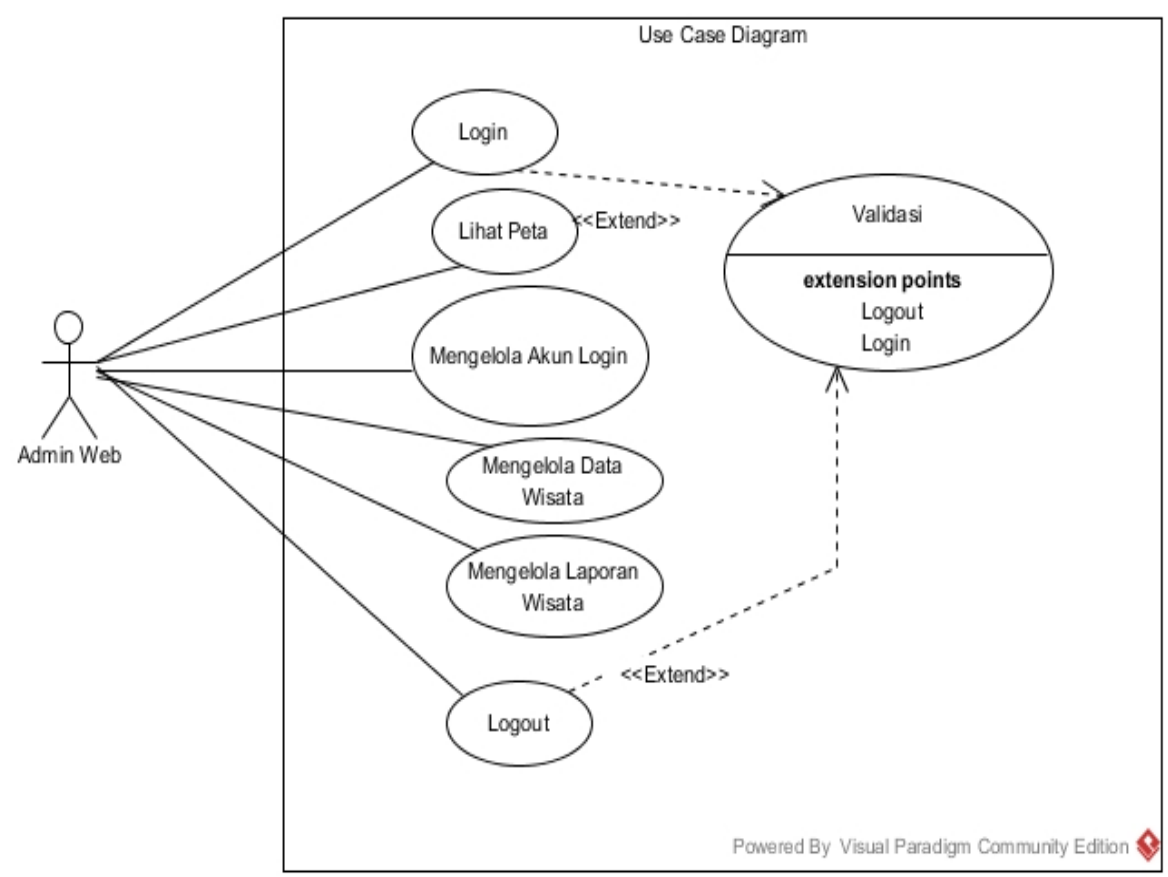

Gambar 2. Use Case Diagram Web

\section{Tampilan Halaman Login}

Halaman Login merupakan halaman awal pada aplikasi berbasis web. Admin diharuskan untuk melakukan login terlebih dahulu sebelum dapat mengakses beranda aplikasi. Tampilan Halaman Login sistem berbasis web disajikan pada Gambar 3.

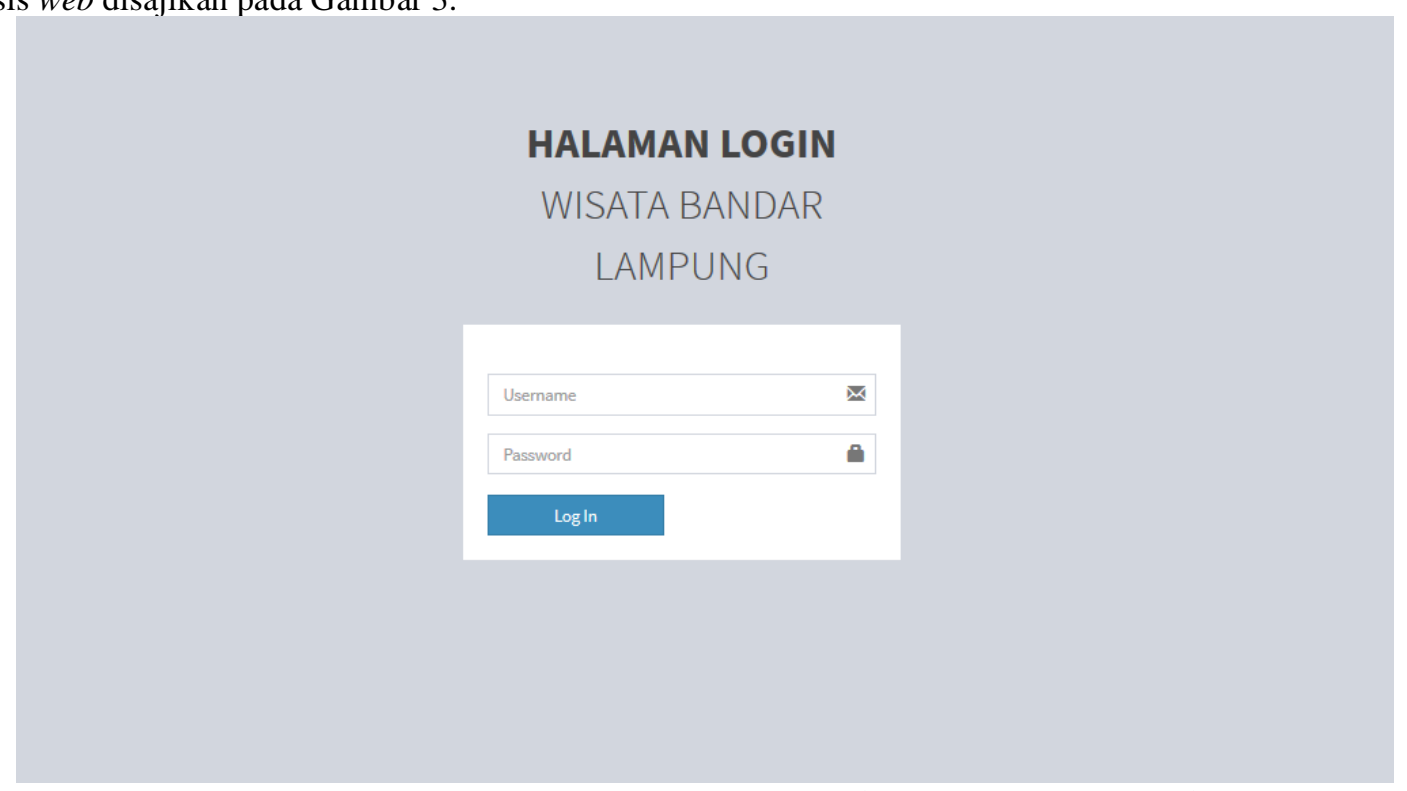

Gambar 3. Halaman Login Sistem Berbasis Web pada Akses Login Admin

\section{Tampilan Halaman Beranda}

Halaman Beranda sistem berbasis web pada akses login admin menampilkan icon dan keterangan singkat mengenai sistem. Pada sisi kiri Halaman Beranda juga disediakan content menu yang dapat diakses oleh admin. Tampilan Halaman Beranda sistem berbasis web disajikan pada Gambar 4. 


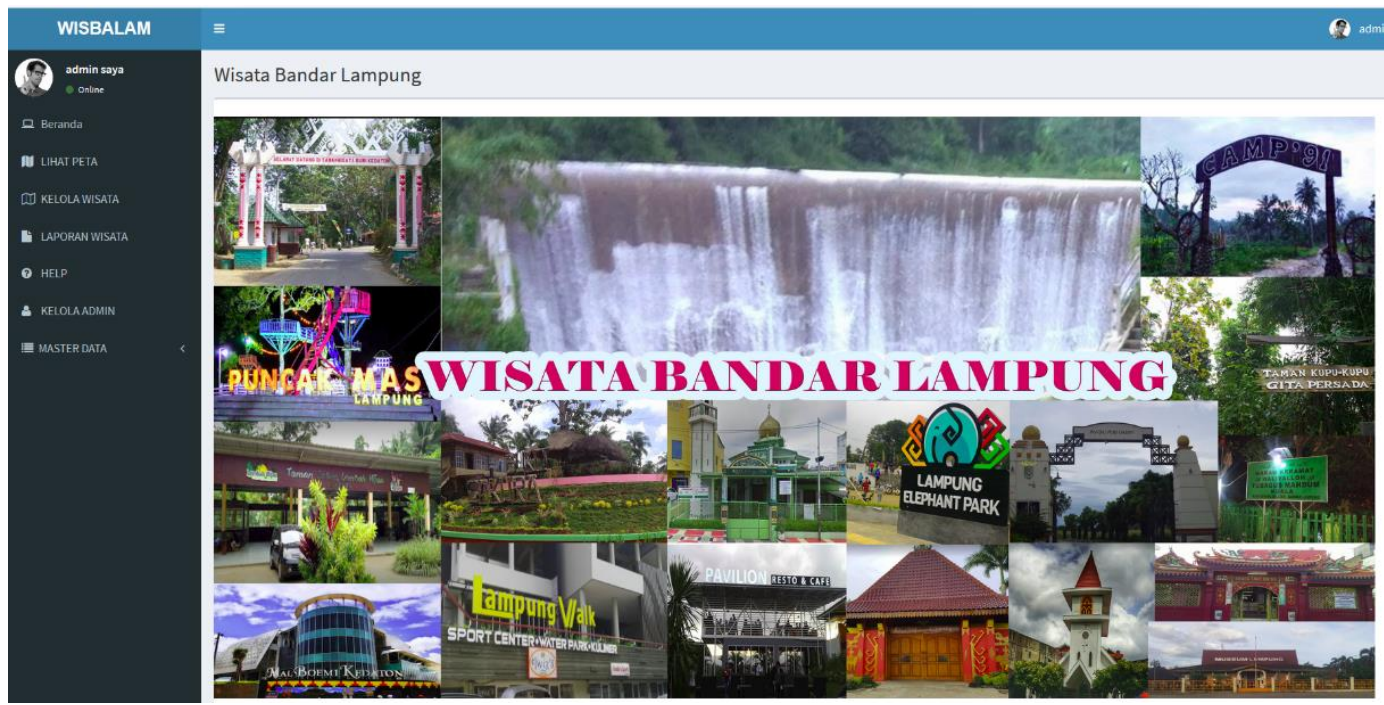

Gambar 4. Halaman Beranda Sistem Berbasis Web pada Akses Login Admin

\section{Halaman Lihat Peta}

Halaman Lihat Peta menampilkan semua wisata yang telah diinput oleh Admin. Lokasi terbagi menjadi 20 kecamatan yang dibedakan dengan warna marker berbeda. Tampilan Halaman Lihat Peta sistem berbasis web disajikan pada Gambar 5. 


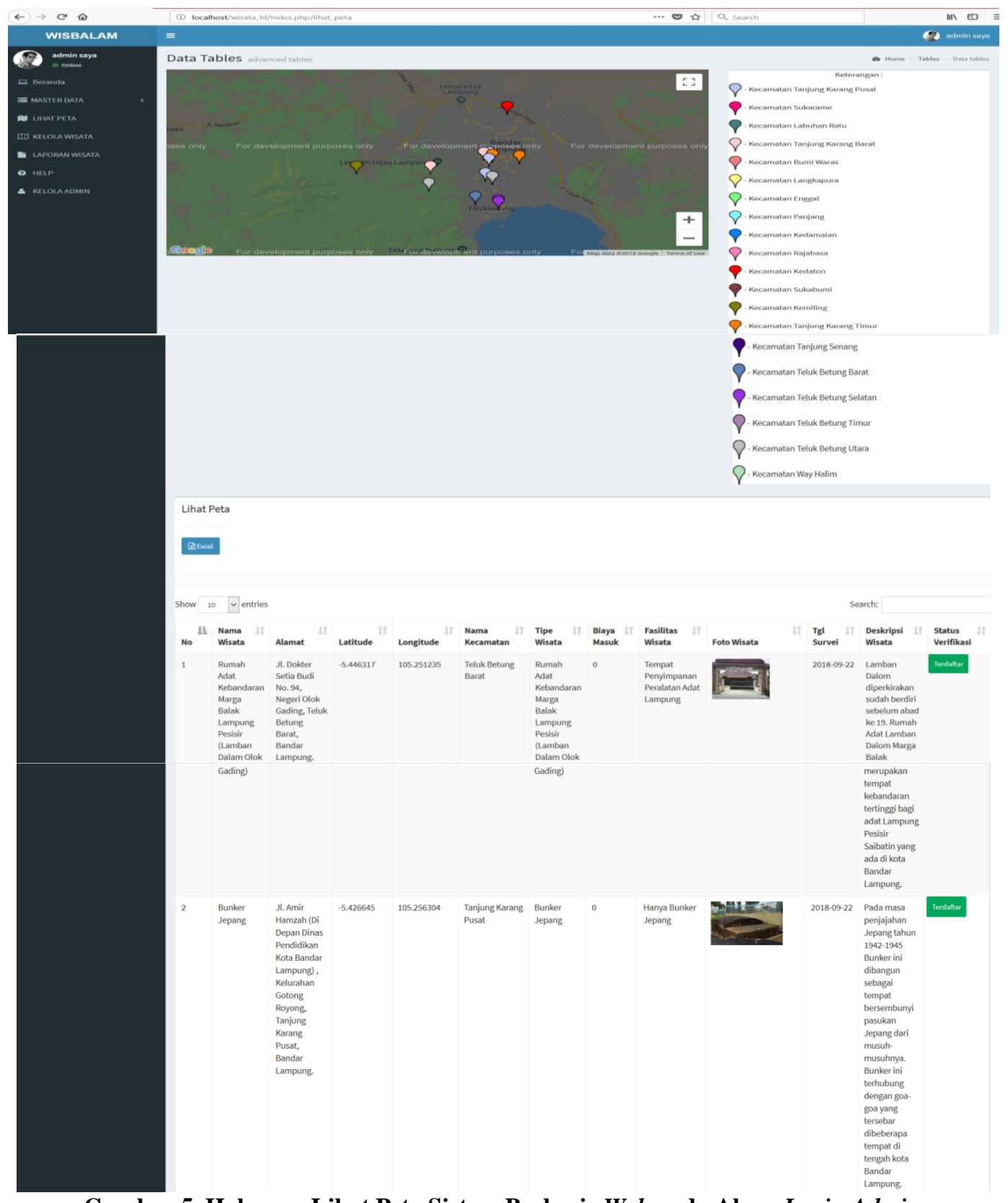

Gambar 5. Halaman Lihat Peta Sistem Berbasis Web pada Akses Login Admin

\section{Halaman Kelola Wisata}

Halaman Kelola Wisata menampilkan semua wisata yang telah diinput oleh Admin dengan warna marker yang berbeda. Selain menampilkan peta persebaran, halaman ini juga menampilkan daftar lokasi dalam bentuk data. Masing-masing data memiliki action button Lihat, Ubah, dan Hapus, juga terdapat button Create. Data Lokasi Wisata dapat dicetak dalam bentuk file excel dengan mengklik button excel yang disediakan. Tampilan Halaman Kelola Wisata sistem berbasis web disajikan pada Gambar 6. 


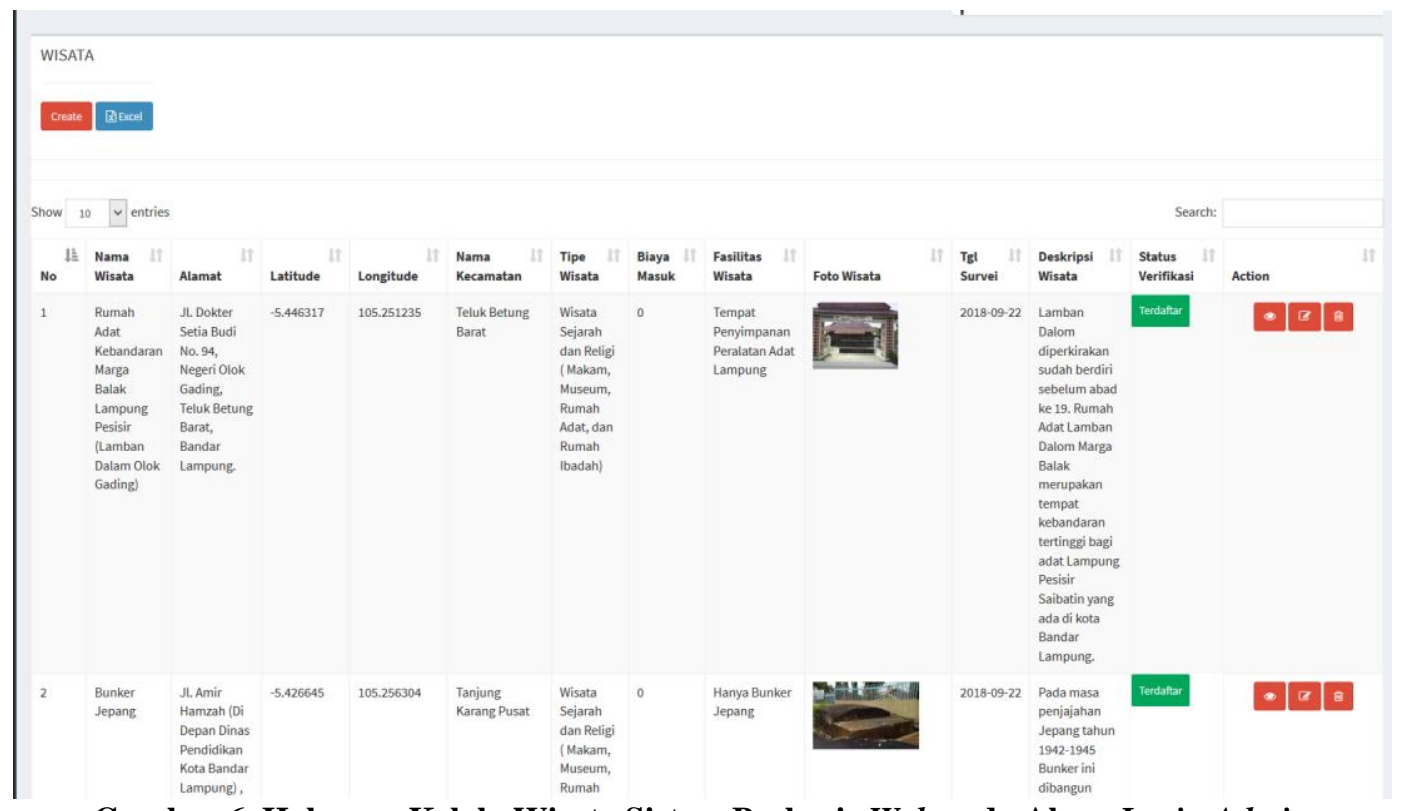

Gambar 6. Halaman Kelola Wisata Sistem Berbasis Web pada Akses Login Admin

\section{Tampilan Halaman Menu Utama}

Halaman Menu Utama Aplikasi menyediakan menu-menu yang disediakan pada aplikasi Android untuk diakses oleh User. Menu-menu tersebut antara lain : Lihat Peta, Daftar Wisata, Semua Wisata dan Cari Wisata, Help, About Us, dan Exit. Tampilan Halaman Menu Utama aplikasi disajikan pada Gambar 7.
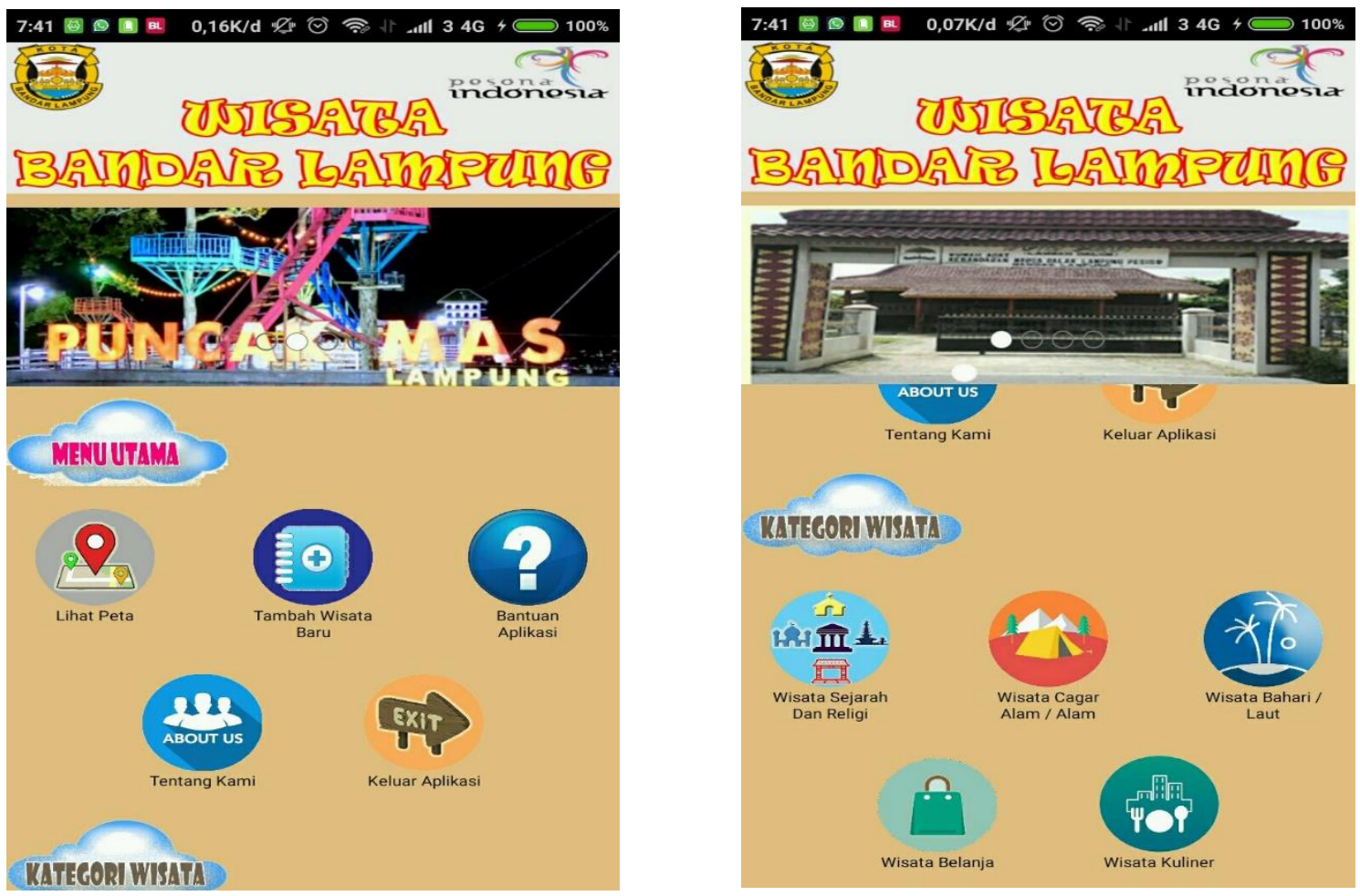

Gambar 7. Tampilan Halaman Lihat Peta

\section{Tampilan Halaman Lihat Peta}

Halaman Lihat Peta menampilkan peta persebaran lokasi wisata yang terdapat di Bandar Lampung. Tampilan Halaman Menu Lihat Peta disajikan pada Gambar 8. 


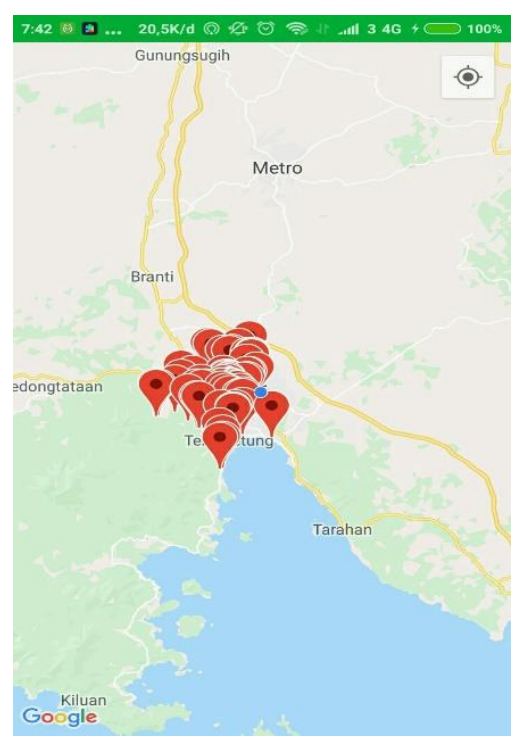

Gambar 8. Tampilan Halaman Menu Lihat Peta

\section{Tampilan Halaman Lihat Peta}

Halaman Semua Wisata dan Cari Wisata menampilkan daftar wisata yang sudah diverifikasi oleh server. Tampilan Halaman Semua Wisata dan Cari Wisata disajikan pada Gambar 9

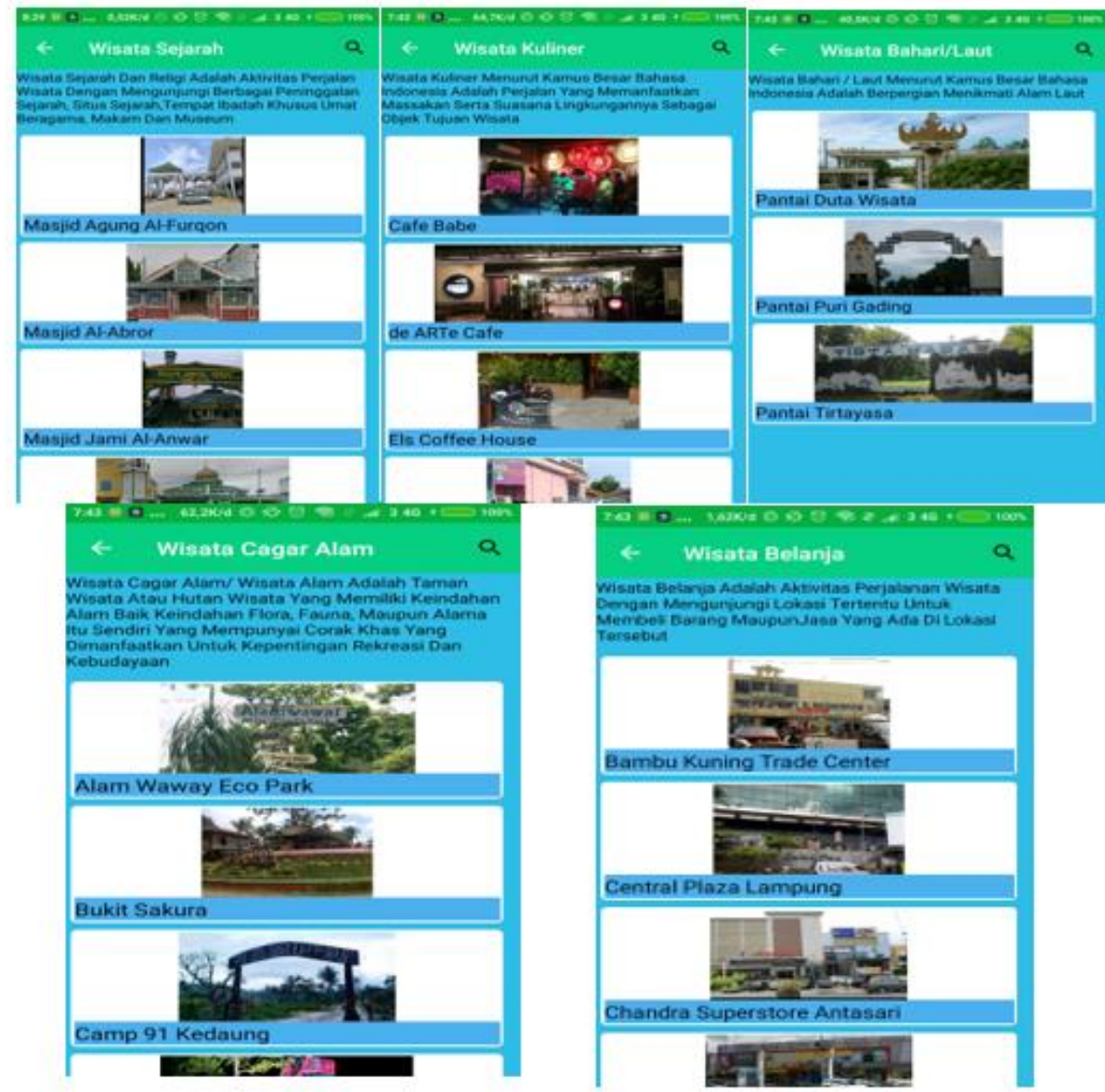

Gambar 9. Tampilan Halaman Menu Wisata Sejarah, Kuliner, Bahari, Cagar Alam, Belanja 


\section{Pengujian Fungsionalitas}

Pengujian dilakukan oleh pihak Dinas Pariwisata Kota Bandar Lampung, yaitu pegawai yang bertindak sebagai admin dan user. Daftar hasil Pengujian Black-Box disajikan pada Tabel 1 dan Tabel 2

Tabel 1. Hasil Pengujian Black-Box pada Sistem Web untuk Admin

\begin{tabular}{|l|l|l|l|}
\hline No. & \multicolumn{1}{|c|}{ Kelas Uji } & \multicolumn{1}{|c|}{ Daftar Pengujian } & \multicolumn{1}{|c|}{ Hasil } \\
\hline 1 & Login Hesuai \\
\hline 2 & $\begin{array}{l}\text { Fungsi Halaman Lihat } \\
\text { Peta }\end{array}$ & Pengujian cetak data & Sesuai \\
\hline 3 & $\begin{array}{l}\text { Fungsi Halaman Kelola } \\
\text { Wisata }\end{array}$ & Pengujian menambah data wisata & Sesuai \\
\hline 4 & $\begin{array}{l}\text { Fungsi Halaman Laporan } \\
\text { Wisata }\end{array}$ & $\begin{array}{l}\text { Pengujian verifikasi pada data } \\
\text { wisata yang baru }\end{array}$ & Sesuai \\
\hline 5 & $\begin{array}{l}\text { Fungsi Halaman Kelola } \\
\text { Admin }\end{array}$ & $\begin{array}{l}\text { Pengujian menambah data admin } \\
\text { baru }\end{array}$ & Sesuai \\
\hline 6 & $\begin{array}{l}\text { Fungsi Halaman Master } \\
\text { Tipe wisata }\end{array}$ & $\begin{array}{l}\text { Pengujian menambah data tipe } \\
\text { wisata }\end{array}$ & Sesuai \\
\hline 7 & $\begin{array}{l}\text { Fungsi Halaman Master } \\
\text { Kecamatan }\end{array}$ & $\begin{array}{l}\text { Pengujian menambah data } \\
\text { kecamatan }\end{array}$ & Sesuai \\
\hline 8 & Fungsi Halaman Help & Pengujian menu help & Sesuai \\
\hline 9 & Logout & Pengujian fungsi logout & Sesuai \\
\hline
\end{tabular}

Tabel 2. Hasil Pengujian Black-Box pada Aplikasi Android untuk pegawai / user

\begin{tabular}{|l|l|l|c|}
\hline No. & \multicolumn{1}{|c|}{ Kelas Uji } & \multicolumn{1}{|c|}{ Daftar Pengujian } & Hasil \\
\hline 1 & Fungsi Halaman Lihat Peta & $\begin{array}{l}\text { Pengujian Info window pada } \text { marker } \\
\text { wisata }\end{array}$ & Sesuai \\
\hline 2 & $\begin{array}{l}\text { Fungsi Halaman Kategori } \\
\text { Wisata dan Cari Wisata }\end{array}$ & Pengujian pencarian nama wisata & Sesuai \\
\hline 3 & Fungsi Halaman Tambah Wisata & Pengujian detail posisi user & Sesuai \\
\hline 4 & $\begin{array}{l}\text { Fungsi Halaman Bantuan } \\
\text { Aplikasi }\end{array}$ & $\begin{array}{l}\text { Pengujian icon tombol bantuan } \\
\text { aplikasi }\end{array}$ & Sesuai \\
\hline 5 & Fungsi Halaman Tentang Kami & $\begin{array}{l}\text { Pengujian tombol icon Tentang } \\
\text { Kami }\end{array}$ & Sesuai \\
\hline 6 & Keluar Aplikasi & Pengujian fungsi Keluar Aplikasi & Sesuai \\
\hline
\end{tabular}

\section{Analisis Hasil Pengujian}

Berdasarkan hasil pengujian pada Tabel 1, dapat diketahui sistem dapat berjalan dengan baik pada akses admin. Hal tersebut juga dapat terlihat pada hasil pengujian pada Tabel 2 untuk pegawai user. Hasil pengujian dari kedua tabel tersebut menunjukkan bahwa sistem dapat berjalan sebagaimana mestinya dan dapat memenuhi kebutuhan fungsional sistem bagi user dengan tidak ditemui kesalahan pada program. Apabila user memberikan input atau perintah yang salah, maka sistem dapat memberikan pesan peringatan kesalahan input agar user dapat mengetahui letak kesalahan dan mengulai proses input. Sistem mudah dimengerti oleh user sehingga dapat disimpulkan bahwa kinerja dari aplikasi sudah sesuai dengan tujuan penelitian cukup baik digunakan bagi admin dan pegawai / user.

\section{SIMPULAN}

Hasil penelitian yang dilakukan, dapat mengambil kesimpulan sebagai berikut yaitu aplikasi berhasil dibangun suatu aplikasi dari Implementasi Restful Service Pada Sistem Informasi Geografis Zona Wisata Kota Bandar Lampung Berbasis Android untuk pencatatan lokasi wisata yang ada di Kota Bandar Lampung dan menampilkan hasil pencatatannya dalam bentuk referensi geografis. Aplikasi Implementasi Restful Service Pada Sistem Informasi Geografis Zona Wisata Berbasis Android yang dibangun berbasis web dan mobile Android. Aplikasi mobile Android bertindak dalam proses pencatatan data lokasi wisata oleh pegawai Dinas Pariwisata Kota Bandar Lampung dengan menggunakan teknologi web service. Berdasarkan data hasil pengujian dengan 
menggunakan metode Black Box Testing, dapat disimpulkan bahwa sistem ini dapat berfungsi sesuai dengan kebutuhan pengguna dan dapat menampilkan data yang dibutuhkan dalam pencatatan lokasi wisata yang ada di Kota Bandar Lampung.

\section{REFERENSI/DAFTAR PUSTAKA}

Agustina, I., \& Isnaini, F. (2020). Sistem Perhitungan dan Pelaporan Pajak Penghasilan Pasal 21 pada Universitas XYZ. Jurnal Ilmiah Infrastruktur Teknologi Informasi (JIITI), 1(2), 24-29.

Ahdan, S., \& Setiawansyah, S. (2020). Pengembangan Sistem Informasi Geografis Untuk Pendonor Darah Tetap di Bandar Lampung dengan Algoritma Dijkstra berbasis Android. Jurnal Sains Dan Informatika: Research of Science and Informatic, 6(2), 67-77.

Ahdan, S., \& Setiawansyah, S. (2021). Android-Based Geolocation Technology on a Blood Donation System (BDS) Using the Dijkstra Algorithm. IJAIT (International Journal of Applied Information Technology), 1-15.

Alim, S., Lestari, P. P., \& Rusliyawati, R. (2020). Sistem Pakar Diagnosa Penyakit Tanaman Kakao Menggunakan Metode Certainty Factor Pada Kelompok Tani Pt Olam Indonesia (Cocoa) Cabang Lampung. Jurnal Data Mining Dan Sistem Informasi, 1(1), 26-31.

Arianto, M. A. (2016). Analisis dan Perancangan Representational State Transfer (REST) Web Service Sistem Informasi Akademik STT Terpadu Nurul Fikri Menggunakan YII Framework. Jurnal Teknologi Terpadu, 2(2).

Budiman, A., Wahyuni, L. S., \& Bantun, S. (2019). Perancangan Sistem Informasi Pencarian Dan Pemesanan Rumah Kos Berbasis Web (Studi Kasus: Kota Bandar Lampung). Jurnal Tekno Kompak, 13(2), 24-30.

Butsianto, S., \& Iskianto, A. (2020). IMPLEMENTASI WEB SERVICE DENGAN METODE REPRESENTATIONAL STATE TRANSFER (REST) UNTUK SISTEM IN FORMASI SALES ORDER BERBASIS MOBILE. Jurnal SIGMA, 10(3), 126-134.

Damayanti, D., \& Sulistiani, H. (2017). Sistem Informasi Pembayaran Biaya Sekolah Pada SD Ar-Raudah Bandar Lampung. Jurnal Teknoinfo, 11(2), 25-29.

Darwis, D., Octaviansyah, A. F., Sulistiani, H., \& Putra, Y. R. (2020). Aplikasi Sistem Informasi Geografis Pencarian Puskesmas Di Kabupaten Lampung Timur. Jurnal Komputer Dan Informatika, 15(1), 159-170.

Fariyanto, F., Suaidah, S., \& Ulum, F. (2021). PERANCANGAN APLIKASI PEMILIHAN KEPALA DESA DENGAN METODE UX DESIGN THINKING (STUDI KASUS: KAMPUNG KURIPAN). Jurnal Teknologi Dan Sistem Informasi, 2(2), 52-60.

Gotama, J. D., Fernando, Y., \& Pasha, D. (2021). Pengenalan Gedung Universitas Teknokrat Indonesia Berbasis Augmented Reality. Jurnal Informatika Dan Rekayasa Perangkat Lunak, 2(1), 28-38.

Kurniawan, I., Setiawansyah, \& Nuralia. (2020). PEMANFAATAN TEKNOLOGI AUGMENTED REALITY UNTUK PENGENALAN PAHLAWAN INDONESIA DENGAN MARKER. Jurnal Informatika Dan Rekayasa Perangkat Lunak, 1(1), 9-16.

Kurniawati, R. (2016). Pengembangan sistem informasi kependudukan berbasis mobile dan restful web service. Seminar Nasional Teknologi Informasi Dan Komunikasi.

Mustaqov, M. A., \& Megawaty, D. A. (2020). Penerapan Algoritma A-Star Pada Aplikasi Pencarian Lokasi Fotografi Di Bandar Lampung berbasis Android. Jurnal Teknoinfo, 14(1), 27-34.

Nugroho, N., Napianto, R., Ahmad, I., \& Saputra, W. A. (2021). PENGEMBANGAN APLIKASI PENCARIAN GURU PRIVAT EDITING VIDEO BERBASIS ANDROID. Jurnal Informasi Dan Komputer, 9(1), 72-78.

Puspaningrum, A. S., Neneng, N., Saputri, I., \& Ariany, F. (2020). PENGEMBANGAN E-RAPORT KURIKULUM 2013 BERBASIS WEB PADA SMA TUNAS MEKAR INDONESIA. Jurnal Komputasi, 8(2), 94-101.

Rahmanto, Y., \& Fernando, Y. (2019). RANCANG BANGUN SISTEM INFORMASI MANAJEMEN KEGIATAN EKSTRAKURIKULER BERBASIS WEB (STUDI KASUS: SMK MA'ARIF KALIREJO LAMPUNG TENGAH). Jurnal Tekno Kompak, 13(2), 11-15.

Rahmanto, Y., Hotijah, S., \& Damayanti. (2020). PERANCANGAN SISTEM INFORMASI GEOGRAFIS KEBUDAYAAN LAMPUNG BERBASIS MOBILE. JDMSI, 1(3), 19-25.

Ramadhanu, P. B., \& Priandika, A. T. (2021). RANCANG BANGUN WEB SERVICE API APLIKASI SENTRALISASI PRODUK UMKM PADA UPTD PLUT KUMKM PROVINSI LAMPUNG. Jurnal Teknologi Dan Sistem Informasi, 2(1), 59-64.

Riskiono, S. D., Hamidy, F., \& Ulfia, T. (2020). Sistem Informasi Manajemen Dana Donatur Berbasis Web Pada Panti Asuhan Yatim Madani. Journal of Social Sciences and Technology for Community Service (JSSTCS), 1(1), 21-26.

Satria, M. N. D., Saputra, F., \& Pasha, D. (2020). MIT APP INVERTOR PADA APLIKASI SCORE BOARD UNTUK PERTANDINGAN OLAHRAGA BERB ASIS ANDROID. Jurnal Teknoinfo, 14(2), 81-88.

Setiawansyah, S., Adrian, Q. J., \& Devija, R. N. (2021). Penerapan Sistem Informasi Administrasi Perpustakaan Menggunakan Model Desain User Experience. Jurnal Manajemen Informatika (JAMIKA), 11(1), 24-36.

Sintaro, S., Ramdani, R., \& Samsugi, S. (2020). Rancang Bangun Game Edukasi Tempat Bersejarah Di. 1(1), 51-57. 
Surahman, A., Octaniansyah, A. F., \& Darwis, D. (2020). Teknologi Web Crawler Sebagai Alat Pengembangan Market Segmentasi Untuk Mencapai Keunggulan Bersaing Pada E-Marketplace. Jurnal Komputer Dan Informatika, 15(1), 118126.

Wahyudi, A. D. (2020). SISTEM INFORMASI INVENTORY GUDANG DALAM KETERSEDIAAN STOK BARANG MENGGUNAKAN METODE BUFFER STOK. Jurnal Informatika Dan Rekayasa Perangkat Lunak, 1(2), 174-182. 